Komunike, Volume XII, No. 2 Desember 2020

\title{
DIGITAL LITERACY AND CYBERBULLYING BEHAVIOR OF YOUTHS IN INSTAGRAM
}

\author{
Marhamah \\ Institut Agama Islam Negeri, Lhokseumawe, Aceh, Indonesia \\ marhamahrusdy@gmail.com \\ Fauzi \\ Universitas Islam Kebangsaan Indonesia, Bireuen, Aceh, Indonesia \\ fauzikalia2017@gmail.com
}

\begin{abstract}
This study aims to describe the level of digital literacy and cyberbullying behavior in youth or adolescents on social media Instagram and to analyze the effect of digital literacy on cyberbullying behavior among adolescents on Instagram social media. This study uses a quantitative approach with a correlational research type. The sampling technique is the total sample, totaling 70 people college students of the Faculty of Economics and Business, Universitas Islam Kebangsaan Indonesia, Bireuen and Instagram users. The results showed that the level of digital literacy in research subjects was high while the level of cyberbullying behavior was low. Digital literacy has a significant effect on cyberbullying behavior by $23.7 \%$ and the remaining $76.3 \%$ is influenced by other neglected variables. Apart from technological factors, internal factors also influence cyberbullying behavior. Internal factors are gender, age, self-esteem, experience as a victim, loneliness, and emotional quotient.
\end{abstract}

Keywords: Digial Literacy, Cyberbullying Behavior, Youth, Instagram

122 Digital Literacy and Cyberbullying Behavior 
Komunike, Volume XII, No. 2 Desember 2020

\begin{abstract}
Abstrak
Penelitian ini bertujuan untuk mendeskripsikan tingkat literasi digital dan perilaku cyberbullying pada remaja di media sosial Instagram dan untuk menganalisis pengaruh literasi digital terhadap perilaku cyberbullying pada remaja di media sosial Instagram. Penelitian ini menggunakan pendekatan kuantitatif dengan jenis penelitian korelasional. Teknik pengambilan sampel adalah total sampel yang berjumlah 70 orang. Kriteria sampel adalah remaja akhir usia 18-21 tahun, pengguna Instagram, dan mahasiswa aktif Fakultas Ekonomi dan Bisnis Universitas Islam Kebangsaan Indonesia, Bireuen. Hasil penelitian menunjukkan bahwa tingkat literasi digital pada subjek penelitian tinggi semenara tingkat perilaku cyberbullying rendah. Literasi digital berpengaruh signifikan terhadap perilaku cyberbullying sebesar 23,7\% dan sisanya 76,3\% dipengaruhi oleh variabel diabaikan lainnya. Selain faktor teknologi, faktor internal juga mempengaruhi perilaku cyberbullying, faktor internal adalah jenis kelamin, usia, harga diri, pengalaman sebagai korban, kesepian, kecerdasan emosional.
\end{abstract}

Kata Kunci: Literasi Digital, Perilaku Cyberbullying, Remaja, Instagram 
Komunike, Volume XII, No. 2 Desember 2020

\section{A. INTRODUCTION}

Along with development of information technology and communication, internet has transformed the real world into cyberspace. In the cyberspace, the distance is not any more confined by space and time; so that the access to information and communication has become easy and speedy. Social networking sites are easily accessed to bridge an interactive communication. Social media has become a life style of the people where everyone at least has one internet account. A survey discovers that instagram is used most of any other social media totalling $79 \%$ of 160 millions users. ${ }^{1}$ The instagram is a media or application in the smartphone which can spread information in images or video. ${ }^{2}$ Therefore, nowadays the instagram

\footnotetext{
1 Social, We are. "Hootsuite." Indonesia Digital 2020, dalam https://andi.link/hootsuite-we-are-socialindonesian-digital-report-2020/

2 Bambang Dwi, A. Instagram Handbook Tips Fotografi Ponsel. (Jakarta: Media Kita, 2012), hlm. 10.

${ }^{3}$ Mustafa Iman, Pengguna Instagram di Indonesia Didominasi Wanita dan Generasi Milenial, Juni 14, 2020), dalam
}

has become trendy among the netizens especially the youths.

A data shows that the users of instagram in Indonesia is dominated by the youths aged $18-34$ years old, the digital world enthusiast, they ae able to explore varieties of devices. ${ }^{3}$ The instagram is mostly used to share the visual contents such as photo or video and user can insert caption and comment or response to the shared contents. Instagram, for the youths as their life style, concerns parents because the youths lack of awareness of negative effect caused by social media one of he effects is cyberbullying. The frequent use of internet indicates that the user is prone to become either a cyberbullyung actor or the victim of the cyberbullying. ${ }^{4}$ Cyberbullying is kind of aggression committed intentionally by a certain netizen by using instant message, e-mail, blog

https://www.goodnewsfromindonesia.id/202 0/06/14/pengguna-instagram-di-indonesiadidominasiwanita-dan-generasi-milenial (20 Juli 2020).

${ }^{4}$ Robin M Kowalski, et al. "Bullying in the digital age: A critical review and metaanalysis of cyberbullying research among youth." Psychological bulletin 140.4 (2014), hlm. 1073. 
Komunike, Volume XII, No. 2 Desember 2020

against someone who are not able to defend themselves.

One of the negative impact that emerge with the this technology development is Cyberbullying. Cyberbullying is any cybercommunication or publication posted or sent by a minor online, by Information Technology devices that is intended to frighten, embarrass, harass, hurt, set up, cause harm to, extort, or otherwise target another minor. ${ }^{5}$ The data obtained from a survey conducted by Ditch the Label, an organization dealing with anti bullying that the instagram is a most used media used to commit cyberbullying. ${ }^{6}$ The other data were collected from Bemfkunud.com which reveal that the rate of cyberbullying in Indonesia rose to

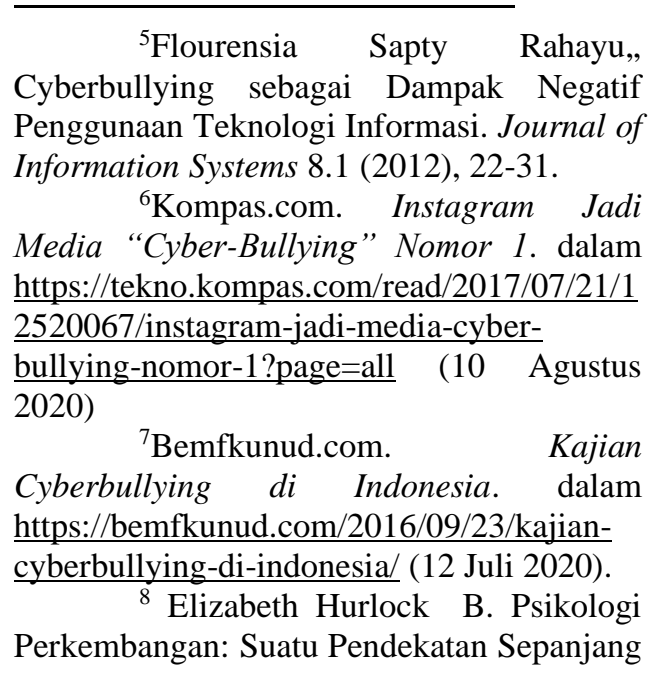

$17 \%$, in the year 2007 rose up to $18 \%$ and to $35 \%$ in the year $2014 .^{7}$

This crime was not only committed by early stage youth, but also it was committed by last stage youth (college students), where their environment affected them to search information and explore himself in order to set their role in the public setting. ${ }^{8}$

The cyberbullying is frequently committed by university students. $^{9}$ That the factor which triggers the cyberbullying behavior is the extreme addicted to using the social media, lack of empathy, once the victim of the bullying. ${ }^{10} \mathrm{~A}$ research conducted by Wangid, shows that $36,25 \%$ of 497 college students admitted having committed cyberbullying. ${ }^{11}$ Macdonald says that

Rentang Kehidupan, (Jakarta: Erlangga, 2016), hlm. 206. http://repo.iainbatusangkar.ac.id/xmlui/handl e/123456789/3414

9 Fadil Arwansyah \& Gazi.
Pengaruh Loneliness, Self-Control, Dan Self Esteem Terhadap Perilaku Cyberbullying Pada Mahasiswa. Tazkiya, Journal of Psychology, 5(2), 2017, 203-215

${ }^{10}$ Fabio Sticca, et al. Longitudinal Risk Factors for Cyberbullying in Adolescence. Journal of Community and Applied Social Psychology, 23(1), 2013. 5267.

${ }^{11}$ Muhammad Nur Wangid, Cyberbullying: Student's Behavior in Virtual 
Komunike, Volume XII, No. 2 Desember 2020

his research reveals that $38 \%$ of 497 college students knew that some other students were undergoing cyberbullying, $\quad 21,9 \% \quad$ college students were undergoing cyberbullying, and 8,6\% committed cyberbullying on other students. ${ }^{12}$

One of cyberbullying cases once happened in instagram is the cyberbullying incidents of students that recently took place in Bandung. A student in Bandung was reported to have bullied one of her friends by taunting her through social media. The victim, who felt unacceptable and hurt at the bullying, finally invited three of his other friends to meet the bully, and responded by hitting and burning cigarettes on his body, alternating with his friends. ${ }^{13}$ The college students should not have committed this kind of bully because

Words. Guidena, Journal of Guidance and Counseling, 6(1), 2016. 38-48.

${ }^{12}$ Christine D MacDonald and Bridget Roberts-Pittman. "Cyberbullying among college students: Prevalence and demographic differences." Procedia-Social and Behavioral Sciences 9 (2010): 20032009.

${ }^{13}$ Dinillah, M. (2017, January 29). Berita. Retrieved June 07, 2020, from DetikNews: https://news.detik.com/berita/d3408218/penganiayaan-mahasiswi-dibandung-berawal-dari-bully-di-medsos they have matured in both physique and spirit, and the college students should avoid bullying people since they are the agent of change; they should have had the sense of responsibility for what they do. ${ }^{14}$ The college student is the last stage youths, that is they should have sense to develop their skill in interpersonal communication and build social interaction among the peers and should strengthen the capacity of selfcontrol.

Cyberbullying is caused by the inability of netizen to maturely understand the digital literacy. ${ }^{15}$ Defines the literacy as the ability to use the digital literacy and also the ability to analyze, to understand, to manage, and to evaluate the digital information. ${ }^{16}$ Defines that digital literacy is a combination of several

14 Fadil Arwansyah \& Gazi. Pengaruh Loneliness, Self-Control, Dan Self Esteem Terhadap Perilaku Cyberbullying Pada Mahasiswa. Tazkiya, Journal of Psychology, 5(2), 2017, 203-215

${ }^{15}$ Sonia Livingstone, et al. Risks and safety on the internet: the perspective of European children: full findings and policy implications from the EU Kids Online survey of 9-16 year olds and their parents in 25 countries. LSE, London: EU Kids Online. (2011), hlm. 26.

16 Murad Maulana, M. (2015).

Definisi, Manfaat, dan Elemen Penting Literasi Digital. dalam 
literacy devices such as computer, information, technology, visual, media and communication. ${ }^{17}$ This definition suggests that the digital information is a multi-discipline skills comprising the ability to learn and to apply knowledge, technique, aptitude, and personal quality in designing, executing and evaluating digital action as an aspect of problem solving in life.

The significant component of the digital literacy is IT Skill, that is the basic skill covering the standard hardware, software, networking application, and information handling skill, that is the capacity to handle the information. ${ }^{18}$ The digital literacy can derive from the source of the literacy itself by questioning why and how. Open-minded to the others is important in applying social media and balanced interactive communication is also required.

https://www.muradmaulana.com/2015/12/definisi-manfaat-dan-elemenpenting-literasi-digital.html (8 Juni 2020).

17 Allan Martin, Digital Literacy and the Digital Society.Digital literacies: Concepts, policies and practices 30 (2008): 151-176.

Informasi: 18 Sitti Husaebah Pattah, Literasi Informasi Peningkatan Kompetensi Khizanah al-Hikmah: Jurnal Ilmu
The concept of digital literacy is extended as an ability to understand and make use of the information deriving from several digital sources. Digital literacy is not just the ability to effectively apply the various sources of digital devices to accesss the information, but also a certain way of thinking. ${ }^{19}$ The digital literacy is a functional skill of a person toward the the digital device, so that the a person can creatively and critically select the information and be able to collaborate and communicate effectively by concerning on the electronic security in case of cultural and social contexts. $^{20}$ Therefore, the digital literacy can be defined as the ability to apply communication media effectively and efficiently.

The bad understanding in digital literacy may affect psyche of children such as tending to despise others, being attracted to forward

Perpustakaan, Informasi, dan Kearsipan 2.2 (2014), 108-119.

${ }^{19}$ Yoram Eshet, Digital Literacy: A conceptual framework for survival skills in the digital era. Journal of educational multimedia and hypermedia 13.1 (2004), 93106.

${ }^{20}$ Cassie Hague and Sarah Payton. Digital literacy across the curriculum. Curriculum Leadership 9.10 (2011) 
Komunike, Volume XII, No. 2 Desember 2020

negative comment using indescent

tendency of cyberbullying behavior words. ${ }^{21}$ In principle, digital literacy is a tool to protect people from chiding in the media. And using the media to express himself in critical thought. $^{22}$ Digital literacy should become a tool to control the information in the media. The higher quality of digital literacy the people have, the higher ability the people have to understand the construction of the world by the media and the real world. The ability to differentiate between social reality and media reality make the youth more critical when using social media and are not easily manipulated. Digital literacy competence in cyberbullying victims, seen from the socio-emotional aspect, is the ability to understand the responsible use of digital media to communicate, socialize and protect privacy rights. ${ }^{23}$ Because the

${ }^{21}$ Nani Pratiwi, and Nola Pritanova. Pengaruh Literasi Digital terhadap Psikologis Anak dan Remaja. Semantik 6.1 (2017). 1124

${ }^{22}$ Yuni Retnowati, Urgensi Literasi Media Untuk Remaja Sebagai Panduan Mengkritisi Media Sosial. Jurnal Perlindungan Aanak dan Remaja. AKINDO. Yogyakarta (2015), 314-331.

${ }^{23} \mathrm{Ng}, \mathrm{W}$. Can we teach digital natives digital literacy?. Computers \& education, 59(3),2012.pp. 1065-1078. 
finding in the text on line, and the competence to identify the validity and the completeness of the information which is referred to by link hypertext; 4) Knowledge assembly is a competence to browse the information thru internet and the competence to crosscheck the retrieved information, the competence to use all types of media to prove the validity of information and the competence to collect the source of information from internet to compare the information from the real world which is not connected with the net working.

Islam in particular has provided guidelines for its followers in responding to the very rapid development of digital media today. This digital literacy ability is called tabayyun, which is absolutely necessary for Muslims to examine any information accessed so that it becomes the character of a Muslim. ${ }^{25}$ As explained in the AlQuran surah Al Hujurat verse 6 which means: O you who believe! If someone who is wicked comes to you with news, then

\footnotetext{
${ }^{25}$ Utomo, Teguh Prasetyo. "Literasi Informasi Di Era Digital Dalam Perspektif
}

research the truth, so that you do not harm a people because of ignorance (carelessness), which in the end you will regret your actions. The verse explains the importance of performing tabayyun, which is evaluating the validity of the information obtained. Even Islam requires examining the credibility of the source and the content of the information itself. In today's digital era, access to information is very easy and fast, so the tabayyun guide in Islamic concepts is a digital literacy competency.

Based on the description mentioned above, understandable that the digital literacy is a knowledge and competence in searching, processing, and delivering information critically, effectively and efficiently in various aspect of daily life. And all competence proposed by Gilster is befitting the operation of instagram because instgram uses internet network. Nevertheless, the competence to use instagram does not automatically mean that someone has competence in digital literacy.

Ajaran Islam." Buletin Perpustakaan (2020): 61-82 
Komunike, Volume XII, No. 2 Desember 2020

Therefore, the competence in digital literacy is required to operate the instagram. The objective of this research is to describe the level of digital literacy and cyberbullying behavior at the youth in instagram and to analyze the effect of digital literacy against the behavior of cyberbullying toward the youth in the instagram.

\section{B. LITERATURE REVIEW}

Literature review on this research has several results writing as a comparison of research. the research conducted by Pratiwi \& Pritanova, "The Effect Of Digital Literation On The Psychology Of Children And Adolescent”. Research result digital literacy is an era of new development in the world of reading and writing. All over information easily obtained through social media. Therefore, understanding the negative effects of digital literacy is necessary emphasized on users, especially children and adolescents. Because, the biggest users Facebook is a child and teenager. They use Facebook as a medium self-actualization. Like two

\footnotetext{
${ }^{26}$ Nani Pratiwi, and Nola Pritanova. Pengaruh Literasi Digital terhadap Psikologis
}

sides of a coin, the era of digital literacy can improve circumstances, can also make things worse. The role of parents is very important in this regard this is to monitor the behavior of children and adolescents. Understanding digital literacy bad will affect the psychology of children and adolescents who tend to insult others, cause envy towards others, lead to depression, got carried away with the mood for negative comments, and used to talking to disrespectful language. ${ }^{26}$

The next research Juliana Kurniawati and Siti Baroroh "Digital Media Literation For Students Of Muhammadiyah Bengkulu University", the result is University student understanding Muhammadiyah Bengkulu regarding digital media is in the medium category which means that a student have sophisticated gadgets such as smartphones the majority do not fully understand use of these gadgets properly and optimal The most dominant factors affect the individual level competence related to digital

Anak dan Remaja. Semantik 6.1 (2017). 1124 
media literacy is a family environment, where roles parents are very big in giving early education regarding digital media. ${ }^{27}$

Reducing crime and maintaining order and the interests of society are the virtues of Islamic teachings, so that punishment ('uquban) is mandated as one of its actions. In the AlQuran surah Al Hujurat verse 11, it is stated which means: "O you who believe, do not let a group of men look down on the other group, maybe those who laugh at it are better than them. And don't even put a group of women down, maybe that's better. And do not be self-deprecating and do not call out with derisive titles. The worst calling is (calling) is bad after faith and whoever does not repent, then they are the wrongdoers". Based on this verse, intimidation and ridicule of others as an act of cyberbullying is prohibited, because Islam highly upholds human honor and dignity. In a formal element, cyberbullying behavior has no scripture that

27 Juliana Kurniawati,and Siti Baroroh. "Literasi Media Digital Mahasiswa Universitas Muhammadiyah Bengkulu. Jurnal Komunikator 8.2 (2016): 51-66. regulates both the Qur'an and the hadiths, but it fulfills the elements in the jarîmah ta'zîr whose punishment is handed over to the ulil amri (ruler), both the determination and implementation. ${ }^{28}$

Research Zahro Malihah and Alfiasari "Cyberbullying Behavior in Adolescents and Its Relation to SelfControl and Parental Communication", research results show that parent-adolescent communication and Adolescent selfcontrol is negatively related with adolescent cyberbullying behavior, so that parents are expected to be more pay attention to manner and intensity communicate with teenagers. Communication hopefully with children and parents channel positive values so that the child can avoid various behaviors

deviate. Teens are also expected have positive self control so can control negative behavior. For the school is expected to provide services that can help children develop positive traits

\footnotetext{
28 Mukhlishotin, Maulida Nur. "Cyberbullying perspektif Hukum Pidana Islam." Al-Jinayah: Jurnal Hukum Pidana Islam 3.2 (2017): 370-402.
} 
Komunike, Volume XII, No. 2 Desember 2020

the child can through the Counseling Guidance service thus preventing negative behavior. ${ }^{29}$ The difference in this study is that the previous research only described digital literacy, cyberbullying behavior in adolescents and the influence of digital literacy on adolescent psychology. Meanwhile, this study further describes the level of digital literacy and cyberbullying behavior in adolescents. This study also analyzes the effect of digital literacy on cyberbullying behavior. So that the results of this study are expected to provide input to minimize the impact of cyberbullying behavior

\section{RESEARCH METHOD}

This research uses quantitative approach; the type of this research is correlational. Quantitative research is the a research conducted to analyze the data numerically in order to see the correlation between one variable with the others and it is based on the certain theories. the correlational research is a non-

29 Zahro Malihah, and Alfiasari. Perilaku Cyberbullying pada Remaja dan Kaitannya dengan Kontrol Diri dan Komunikasi Orang Tua. Jurnal Ilmu Keluarga \& Konsumen 11.2 (2018), 145-156. experimental research where the goal of which is to measure the statistical correlation between one variable with the others. ${ }^{30}$ The population of this research is 70 last stage youths, they are all active college students, studying at faculty of Economics, Universitas Islam Kebangsaan Idonesia (UNIKI), Bireuen, who was using instagram.

The sampling technique is the total sample, that is, the number of samples is equal to the number of population. Samples are students of the Faculty of Economics and Business, Indonesian National Islamic University, Bireuen and users of Instagram media. The data collection was conducted by using questionnaire of linkert model at two scales, that is digital literacy scale and cyberbullying behavior scale. Research instrument has gone thru the validity test, this test is required to know the precision, and reliability test was also carried out to measure the reliability and consistency. The data

30 Sugiyono. Metode Penelitian Kuantitatif, Kualitatif, dan R\&D, (Bandung: Alfabeta, 2019), hlm. 121. 
was analyzed by using technical analysis of simple linier regression.

\section{RESULTS AND DISCUSSION}

Description of Digital Literacy and Cyberbullying Behavior of Youths in Instagram is as follow:

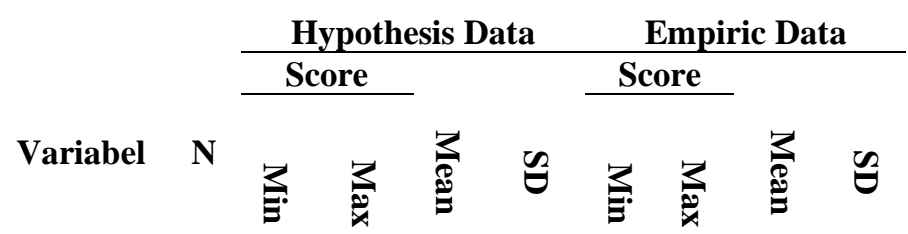

\begin{tabular}{ccccccccccc}
\hline $\begin{array}{c}\text { Digital } \\
\text { Literacy }\end{array}$ & 70 & 25 & 100 & 63 & 12,5 & 62 & 98 & $\begin{array}{c}77,8 \\
1\end{array}$ & 6, \\
\hline $\begin{array}{c}\text { Cyber } \\
\text { Bullying } \\
\text { Behavio } \\
\text { r }\end{array}$ & 70 & 27 & 108 & 68 & 13,5 & 31 & 65 & $\begin{array}{c}46,5 \\
1\end{array}$ & 9, \\
&
\end{tabular}

The table above shows that mean digital literacy scale is 63 by standard deviation 12,5, it indicates that mean of empiric is bigger than mean of hypothesis $(77,81>63)$, meaning that the average of the subject of the research had a high level of digital literacy. There are four indicators of digital literacy in this study, namely 1). Internet Searching, namely the ability to use and perform various activities on the internet. 2). Hypertextual Navigation, namely knowledge of how to browse hypertext and hyperlinks, 3). Content
Evaluation, namely the ability to think critically to identify the validity of information. 4). Knowledge Assembly, namely the ability to collect information from various sources and evaluate for further information from these various information can be formed a new knowledge.

Then, at the scale of cyberbullying, mean of hypothesis is 68 by standard deviation 13,5 and mean of empiric was 46,51 by standard deviation 9,07, this indicates that mean of empiric is lower than mean of hypothesis $(46,51<68,00$. This indicates that the average of the research subject had lower tendency toward cyberbullying behavior. There are seven indicators of cyberbullying behavior in this study, namely: flaming, harassment, denigration, impersonation, outing and trickey, exclusion and cyberstalking.

After obtaining the result from the data description, the researcher categorized each scale in order to put the subjects at each scale in tiered position, that is high, medium, low. The digital literacy data 
Komunike, Volume XII, No. 2 Desember 2020

categorization used mean formula and standard deviation as follows:

\begin{tabular}{cccc}
\hline $\begin{array}{c}\text { Digital } \\
\text { Litarcy }\end{array}$ & Score X & Subject & Percentage \\
\hline Low & $X<50$ & 0 & $0 \%$ \\
\hline Medium & $\begin{array}{c}50 \leq \mathrm{X}< \\
\end{array}$ & 15 & $21,42 \%$ \\
\hline High & $80<\mathrm{X}$ & 55 & $78,57 \%$ \\
\hline
\end{tabular}

Table 2 Categorization of Digital Literacy Data

Based on the table 2 above, it can be seen that no subject has a low digital literacy level, and as many as $21,42 \%$ or 15 subjects have a moderate digital literacy level while the subject has a high digital literacy level of $78,57 \%$ or 55 .

Table 3. Data Categorization of Cyberbullying Behavior

Based on the table 3 above, we know that there is no subject who have high score at cyberbullying behavior. The cyberbullying has medium score of $28.57 \%$ or 20 subjects. The subject who have low score at cyberbullying $71,42 \%$ or 50 subjects.

\section{The Effect of Digital Literacy toward Cyrberbullying Behavior of the Youths in Instagram}

The analysis of the effect of digital literacy (X) toward cyberbullying behavior (Y) was conducted by analyzing simple linier regression which was based on decision making.

1. If the value of $t$ count is greater $>$ than $\mathrm{t}$ table; if the hypothesis says there is an effect on variable $\mathrm{X}$ against $Y$, it is acceptable.

\begin{tabular}{cccc}
\hline $\begin{array}{c}\text { Cyberbullying } \\
\text { Behavior }\end{array}$ & Score X & Subject & Percentage \\
\hline Low & $\mathrm{X}<54$ & 50 & $71,42 \%$ \\
\hline Medium & $54 \leq \mathrm{X}$ & 20 & $28.57 \%$
\end{tabular}

\begin{tabular}{l}
$<81$ \\
\hline High $81<\mathrm{X} \quad 0$ \\
\hline 2. If value of $\mathrm{t}$ count is smaller $<$ than \\
$\mathrm{t}$ table, so the hypothesis which \\
says there is an effect on variable \\
$\mathrm{X}$ against $\mathrm{Y}$, it is rejected.
\end{tabular}


Coefficients $^{\mathrm{a}}$

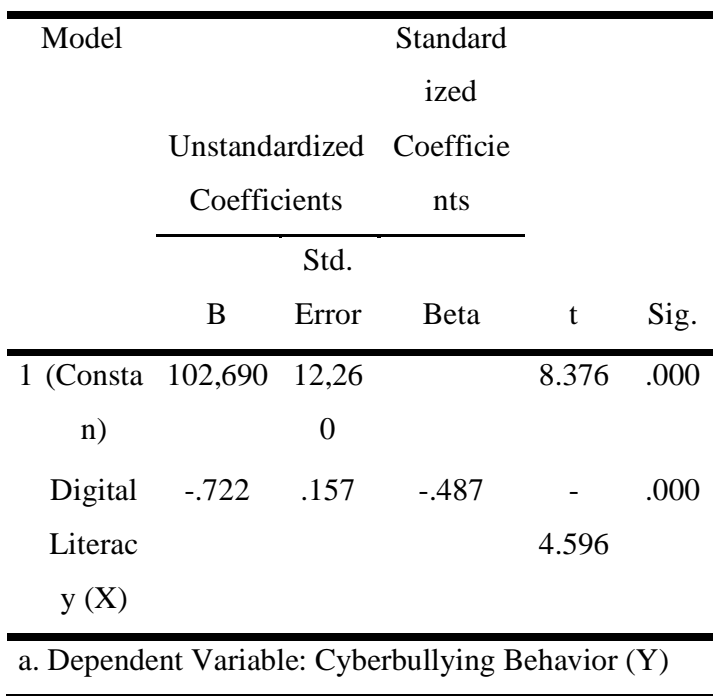

Table 4. Result of Hypothesis

Test

The table 4 above shows that $t$ count -4.596 is greater than $t$ table 0.1891 (-4.596 > 0.1891), and Sig.p $0.000<0,05$, so it can concluded that there is a significant effect of variable $\mathrm{X}$ against $\mathrm{Y}$. The constanta value is 102,690 meaning that if there is no digital literacy $(\mathrm{X})$, the consistent value of cyrberbullying behavior (Y) 102,690. thus, the beta value is unstandardized coefficient variable of digital literacy variable $(\mathrm{X})$ indicates the number $-0,722$ meaning that each increment of $1 \%$ the level of digital literacy (X), so the cyberbullying behavior (Y) decreases to $72,2 \%$. Negative coefficient value indicates that there is negative relationship between digital literacy variable and cyberbullying behavior (Y). So, the conclusion is that the higher digital literacy, the lower cyberbullying occurs.

Besides what was described previously, the test of determination coefficient was also conducted to see the closeness of the effect digital literacy $(\mathrm{X})$ against the cyberbullying behavior (Y). By stipulating that the value of $R^{2}$ is located between 0 to 1 $\left(0 \leq \mathrm{R}^{2} \leq 1\right)$. If $\mathrm{R}^{2}$ is closed to 1 $(100 \%)$, so the calculation result indicates that the better or the more straight the regression line obtained. On the contrary, if $\mathrm{R}^{2}$ is closed to 0 , so it indicates that the regression line is more diverted to measure the observation data.

\begin{tabular}{|c|c|c|c|c|c|}
\hline Mode & $\mathrm{R}$ & $\begin{array}{c}\mathrm{R} \\
\text { Square }\end{array}$ & $\begin{array}{c}\text { Adjusted } \\
\text { R } \\
\text { Square }\end{array}$ & $\begin{array}{c}\text { Std. } \\
\text { Error of } \\
\text { the } \\
\text { Estimate }\end{array}$ & Sig. \\
\hline 1 & $.487^{\mathrm{a}}$ & .237 & .266 & 7.98844 & $.000^{\mathrm{a}}$ \\
\hline
\end{tabular}

Tabel 5. The Test Result of

Determination Coefficient

The table of Sumary Model indicates that determination coefficient of digital literacy variable (X) with the cyberbullying behavior 
Komunike, Volume XII, No. 2 Desember 2020

variable (Y) amounts R Square 0,237. It means that the digital literacy $(\mathrm{X})$ against cyrberullying behavior (Y) amounts $23,7 \%$, the remaining is $76,3 \%$ affected by the other ignored variables.

The research result mentioned above indicates that the digital literacy is significantly affected by cyberbulying behavior. The negative correlation value indicates that digital literacy $(\mathrm{X})$ has the relationship in the opposite direction with the cyberbullying behavior (Y). It means that the increment happens at digital literacy variable; consequently, the decrease occurs at cyberbullying behavior, it can be inferred that the higher digital literacy value, the lower the cyberbullying behavior of the youths in instagram, and vice versa

The result shows that one of the internal factors which affects cyberbullying is social media. ${ }^{31}$ Another internal factor that influences

${ }^{31}$ Siti Robiah Adawiyah, Literatur Review: Faktor-Faktor yang Mempengaruhi Cyberbullying pada Remaja. Seminar Nasional Magister Psikologi Universitas Ahmad Dahlan, 2018, 398-403.

32 Fernandez, G. C. Literatur Review: Faktor-Faktor Yang Mempengaruhi Cyberbullying Pada Remaja. Proceedings of cyberbullying behavior is the perpetrator's experience as a victim. Exposure to violence by the surrounding environment increases the likelihood of a tendency for cyberbullying behavior, especially in adolescents who do not get enough attention from their parents. This aggressive behavior is obtained through an observational learning process, so that the experience of being a victim of violence, either directly or through social media, can influence the emergence of a tendency for cyberbullying behavior. $^{32}$

The internal factor that triggers cyrberbullying is the use of social media rated $24 \%$. The other factors which are ignored in this research are gender, age, pride, experience, victim, loneliness, and emotional quotient. ${ }^{33}$ As described by Kowalski stating that the frequency of using internet tends to become the

Psychology" Cyber Effect: Internet Influence on Human Life", (2018). 18-28.

${ }_{33}$ Anastasiaa Siwi Fatma Utami and Nur Baiti. Pengaruh Media Sosial terhadap Perilaku Cyberbullying pada Kalangan Remaja. Cakrawala-Jurnal Humaniora 18.2 (2018): 257-262. 
actor of cyberbullying or the victim of this media. $^{34}$ The victim of the cyberbullying cannot easily defend his/herself because the bullying is done in the context of electronic intercommunication.

Patton el.al states that in the last several years internet and social media contributes creating the juvenal delinquency and cyrberbullying occurred in Indonesia were committed by the youths. ${ }^{35}$ Many cases of cyberbullying in Indonesia caused by the obscurity between space for private and space for public in the social media; therefore, the development of communication technology must be addressed wisely thru digital literacy. This advise is in line with the theory proposed by Gilster (1997) stating that social media is a source of digital information to access bulk of information in various context in daily life. The use this technology

34 Robin M Kowalski, et al. "Bullying in the digital age: A critical review and meta-analysis of cyberbullying research among youth." Psychological bulletin 140.4 (2014), hlm. 1073.

${ }^{35}$ Patton, D., Hong, J., Ranney, M., Patel, S., Kelley, C., Eschmann, R., \& should be supported by competency, which is called competency in digital literacy. ${ }^{36}$

Digital literacy is not only to make use of technology, but also the users is required to use critical thinking to evaluate and digest the information conveyed by digital media. Gilster (1997) groups the digital literacy in four core competencies; 1) The competency to use internet and apply it for various purposes.2) The competency to comprehend dynamically the navigation or hypertext guide in web browser. 3) The competence to think critically and evaluate what they have discovered in online media. 4) The competence to recheck the information and usedigital media to prove the reliability of the retrieved information.

Digital literacy in principle is a tool used to protect someone from any attack channeled thru media. The

Washington, T. Social media as a vector for youth violence: A review of the literature. Computers In Human Behavior, 35,(2014), 548-553

36 Paul Gilster and Paul Glister. Digital literacy. (New York: Wiley Computer Pub., 1997), hlm. 139. 
Komunike, Volume XII, No. 2 Desember 2020

user should have the competence to participate in the media and express his/herself with a critical thinking. ${ }^{37}$ So the digital literacy should become a reference to control the information from the media. Having a high competency in digital literacy, the user of the media will have high understanding in world structure engineered by the media and real world. The competence to differentiate between social reality and media reality; thus making the youths more critical when using the social media and they are not easily manipulated.

A research was conducted by Coral in (Pattah, 2014) mentions that theimportant component of the digital literacy is information skill, that is the competence to handle and make use of information technology such as device, internet, other applications. Information handling is the skill to handle the information. ${ }^{38}$ Digital

\footnotetext{
37 Yuni Retnowati, Urgensi Literasi Media Untuk Remaja Sebagai Panduan Mengkritisi Media Sosial. Jurnal Perlindungan Aanak dan Remaja. AKINDO. Yogyakarta (2015), 314-331.

$\begin{array}{rrr}38 & \text { Sitti Husaebah Pattah, Literasi } \\ \text { Informasi: } & \text { Peningkatan } & \text { Kompetensi }\end{array}$
}

literacy is a competency related with cognitive skill, emotion and social circumstances since the digital devices does not only contain the application but also the information; therefore, the digital literacy is necessarily used in instagram. In view of the many cyberbullying cases occurs among the youths through instagram, it indicates that most of the youths still lack competency in digital literacy. Based on the assumption of this research that the high digital literacy will decrease the cyberbullying behavior.

Based on the results of interviews, researchers with research subjects show that they provide comments on photos or videos uploaded on Instagram that are intended for jokes only. ${ }^{39}$ Although the comments made can offend or hurt the person who received them. In addition, there are also subjects who directly disseminate the information

Informasi Dalam Proses Pembelajaran. Khizanah al-Hikmah: Jurnal Ilmu Perpustakaan, Informasi, dan Kearsipan 2.2 (2014), 108-119.

39 Wawawncara dengan Li, Mahasiswa Febi UNIKI, Bireuen 
they receive without examining the validity of the information. ${ }^{40}$ The aim is to follow the trend of who is first to convey information. Based on the researcher's insight, most subjects do not fully realize that what they are doing is cyberbullying behavior, so they also do not realize further the very worrying impact of this behavior.

The advanced development of internet gives the impact on the use of social media; it seems the media has become the basic need for the youths. Social media is used as communication and interaction media by the youths. To address this phenomena, the experts in communication science should study the digital literacy deeper. The significance of digital literacy shows that many experts in communication from Europe, America, Africa, and Asia have been conducting the massive research on the digital literacy. Recently, 843 articles on digital literacy have been issued both written by single writer and a

$40 \quad$ Wawawncara dengan
Me, collaboration by several writers. They are David Bawden, Gloria E. Jacobs, Sonia Livingstone , Guy Merchant and Ezter Hargittai. ${ }^{41}$ This indicates that the field of digital literacy attracted the interest of the experts to work together to develop the study in digital literacy.

\section{E. CONCLUSION}

The level of competency in digital literacy at the average of the subject of the research is high totaling 55 persons or $78,57 \%$, the remaining is 15 persons or $21,42 \%$, which pose at medium level. The level of cyberbullying behavior at the average of the research subject is categorized as low totaling 50 persons or $71,42 \%$, the remaining is 20 persons or $28.57 \%$, which is categorized as medium. This indicates that the subjects of the research are not only competent in using the social media but also they have had critical thinking on the information they obtained from internet or social media. They also can identify the

${ }^{41}$ Mathar, T. Authors Collaboration in Digital Literacy From 1997 to 2013 : a bibliometric study. Khizanah Al Hikmah, 2(2),(2014), 149-160 
Komunike, Volume XII, No. 2 Desember 2020

validity of the information, recheck and used digital media to prove the validity of the information.

Digital literacy significantly affected the cyberbullying behavior totaling $23,7 \%$ and the remaining are $76,3 \%$ was affected by the other ignored variables. Besides the technological factor, the internal factors also affected the cyberbullying behavior, the internal factors are gender, age, self-esteem, experience as a victim, loneliness, emotional quotient. This indicates that the significance of digital literacy in order to enable the users to digest any online information critically and selectively.
Based on this research, it is suggested to the next researchers to follow up this research on aspects that have not been researched on cyberbullying behavior, both internal and external aspects as the development of Islamic communication. Then it is suggested for students to improve their digital literacy skills in using social media effectively and efficiently and to understand it with an Islamic perspective. In addition, it is also recommended to increase awareness of the impact of cyberbullying on oneself and others so that it is not easy to manipulate or manipulate which can lead to becoming the perpetrator or victim of cyberbullying. 


\section{F. REFERENCES}

Adawiyah, Siti Robiah. Literatur Review: Faktor-Faktor yang Mempengaruhi Cyberbullying pada Remaja. Seminar Nasional Magister Psikologi Universitas Ahmad Dahlan, 2018, 398-403. http://seminar.uad.ac.id/index.ph $\mathrm{p} / \mathrm{snmpuad} /$ article/view/3466

Anwarsyah, Fadhli. \& Gazi. Pengaruh loneliness, self-control, dan self esteem terhadap perilaku cyberbullying pada mahasiswa. Tazkiya, Journal of Psychology, 5(2), 2017. 203-215. https://doi.org/10.15408/tazkiya. $\mathrm{v} 22 \mathrm{i} 2.8401$

Dinillah, M. (2017, January 29). Berita. Retrieved June 07, 2020, from DetikNews: https://news.detik.com/berita/d3408218/penganiayaanmahasiswi-di-bandung-berawaldari-bully-di-medsos

Dwi, A. Bambang,. Instagram Handbook Tips Fotografi Ponsel. Jakarta: Media Kita, 2012.

Eshet, Yoram. "Digital literacy: A conceptual framework for survival skills in the digital era." Journal of educational multimedia and hypermedia 13.1 (2004): 93-106. https://www.learntechlib.org/pri mary/p/4793/.

Fernandez, G. C. Literatur Review: Faktor-Faktor Yang Mempengaruhi Cyberbullying Pada Remaja. Proceedings of Psychology" Cyber Effect: Internet Influence on Human Life", (2018). 18-28.

Gilster, Paul, and Paul Glister. Digital literacy. New York: Wiley Computer Pub, 1997.

Hague, Cassie, and Sarah Payton. Digital literacy across the curriculum. Curriculum Leadership $9.10 \quad$ (2011), http://www.curriculum.edu.au/le ader/vol9 no10,33010.html?issu $\underline{\mathrm{eID}=12380}$.

Hurlock, Elizabeth, B. Psikologi Perkembangan: Suatu Pendekatan Sepanjang Rentang Kehidupan. Jakarta: Erlangga, 2016.

http://repo.iainbatusangkar.ac.id/ $\underline{\text { xmlui/handle/123456789/3414 }}$

Kowalski, Robin M., et al. "Bullying in the digital age: A critical 
Komunike, Volume XII, No. 2 Desember 2020

review and meta-analysis of cyberbullying research among youth." Psychological bulletin 140.4 (2014). $1073 . \quad$. https://psycnet.apa.org/buy/2014 $\underline{-04307-001}$

Kurniawati, Juliana, and Siti Baroroh. "Literasi Media Digital Mahasiswa Universitas Muhammadiyah Bengkulu. Jurnal Komunikator 8.2 (2016): 51-66.

https://journal.umy.ac.id/index.p $\underline{\mathrm{hp} / \mathrm{jkm} / \mathrm{article} / \mathrm{view} / 2069}$

Livingstone, Sonia, et al. Risks and safety on the internet: the perspective of European children: full findings and policy implications from the EU Kids Online survey of 9-16 year olds and their parents in 25 countries. LSE, London: EU Kids Online. (2011).

https://www.researchgate.net/pu blication/50902989_Risks_and Safety_on_the_Internet_The_Per spective_of_European_Children _Full_FINDINGS

MacDonald, Christine D., and Bridget Roberts-Pittman. "Cyberbullying among college students:
Prevalence and demographic differences." Procedia-Social and Behavioral Sciences 9 (2010): 2003-2009. https://doi.org/: 10.1016/j.sbspro.2010.12.436 Malihah, Zahro, and Alfiasari. Perilaku Cyberbullying pada Remaja dan Kaitannya dengan Kontrol Diri dan Komunikasi Orang Tua. Jurnal Ilmu Keluarga \& Konsumen 11.2 (2018), 145156.

https://doi.org/10.24156/jikk.201 $\underline{8.11 .2 .145}$

Martin, Allan. Digital Literacy and the Digital Society"." Digital literacies: Concepts, policies and practices 30 (2008): 151-176. https://www.researchgate.net/pu blication/291334632_Digital_Lit eracies_Concepts_Policies_and $\underline{\text { Practices_Cover_plus_Introducti }}$ on

Mathar, T. (2014). Authors Collaboration in Digital Literacy From 1997 to 2013 : a bibliometric study. Khizanah Al Hikmah, 2(2), 149-160. http://journal.uinalauddin.ac.id/index.php/khizana h-al-hikmah/article/view/131 
Mukhlishotin, Maulida Nur. Remaja. Semantik 6.1 (2017). "Cyberbullying perspektif 11-24.

Hukum Pidana Islam." $A l$ https://doi.org/10.22460/semanti

Jinayah: Jurnal Hukum Pidana Islam 3.2 (2017): 370-402.

$\mathrm{Ng}, \mathrm{W}$. Can we teach digital natives digital literacy?. Computers \& education, 59(3),2012.pp. 1065-1078.

Pattah, Sitti Husaebah. Literasi Informasi: Peningkatan Kompetensi Informasi Dalam Proses Pembelajaran.Khizanah al-Hikmah: Jurnal Ilmu Perpustakaan, Informasi, dan Kearsipan 2.2 (2014), 108-119. http://journal.uin-

alauddin.ac.id/index.php/khizana h-al-hikmah/article/view/146

Patton, D., Hong, J., Ranney, M., Patel, S., Kelley, C., Eschmann, R., \& Washington, T. Social media as a vector for youth violence: A review of the literature. Computers In Human Behavior, 35,(2014), 548-553. https://doi.org/:10.1016/j.chb.20 $\underline{14.02 .043}$

Pratiwi, Nani, and Nola Pritanova. Pengaruh Literasi Digital Terhadap Psikologis Anak Dan k.v6i1.p11-24

Rahayu, Flourensia Sapty. Cyberbullying Sebagai Dampak Negatif Penggunaan Teknologi Informasi. Journal of Information Systems 8.1 (2012): 22-31. https://jsi.cs.ui.ac.id/index.php/js i/article/view/321

Retnowati, Yuni. Urgensi literasi media untuk remaja sebagai panduan mengkritisi media sosial. Jurnal Perlindungan Aanak dan Remaja. AKINDO. Yogyakarta (2015), 314-331. fhttp://akindo.ac.id/downlot.php ?file=13Urgensi Literasi Media untuk Remaja Sebagai Panduan Mengkritisi Media Sosial.pdf Sticca, F., Ruggieri, S., Alsaker, F., \& Perren, S. Longitudinal Risk Factors for Cyberbullying in Adolescence. Journal of Community and Applied Social Psychology, 23(1), 2013. 52-67. https://doi.org/https://doi.org/10. $\underline{1002 / \text { casp.2136 }}$

Sugiyono. Metode Penelitian Kuantitatif, Kualitatif, dan R\&D. 
Komunike, Volume XII, No. 2 Desember 2020

Bandung: Alfabeta, 2019.

https://bemfkunud.com/2016/

http://cvalfabeta.com/product/m

09/23/kajian-cyberbullying-

etode-penelitian-kuantitatif-

di-indonesia/ (12 Juli 2020).

kualitatif-dan-rd-mpkk/

Utami, Anastasiaa Siwi Fatma, and

Nur Baiti. Pengaruh Media Sosial

terhadap Perilaku Cyberbullying

pada Kalangan Remaja.

Cakrawala-Jurnal Humaniora

18.2 (2018): 257-262.

https://ejournal.bsi.ac.id/ejurnal/i

ndex.php/cakrawala/article/view $\underline{13680}$

Utomo, Teguh Prasetyo. "Literasi

Informasi Di Era Digital Dalam

Perspektif Ajaran Islam." Buletin

Perpustakaan (2020): 61-82.

Wangid, Muhammad Nur.

Cyberbullying: Student's

Behavior In Virtual Worlds.

Guidena: Jurnal Ilmu

Pendidikan, Psikologi,

Bimbingan dan Konseling. 6.1

(2016). $38 \quad-\quad 48$.

https://doi.org/10.24127/gdn.v6i

1.412

Website:

Bemfkunud.com. Kajian

Cyberbullying di Indonesia. dalam

Iman, Mustafa, Pengguna Instagram

di Indonesia Didominasi

Wanita dan Generasi

Milenial, Juni 14, 2020),

dalam

https://www.goodnewsfromin

donesia.id/2020/06/1

4/pengguna-instagram-di-

indonesia-didominasiwanita-

dan-generasi-milenial (20 Juli 2020).

Kompas.com. Instagram Jadi Media

"Cyber-Bullying" Nomor 1.

dalam

https://tekno.kompas.com/rea

d/2017/07/21/12520067/insta

gram-jadi-media-cyber-

bullying-nomor-1?page $=$ all

(10 Agustus 2020)

Maulana, M. (2015). Definisi, Manfaat, dan Elemen Penting Literasi Digital. Dalam https://www.muradmaulana.c om/-2015/12/definisi-

manfaat-dan-elemen-penting-

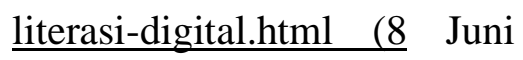
2020). 
Komunike, Volume XII, No. 2 Desember 2020

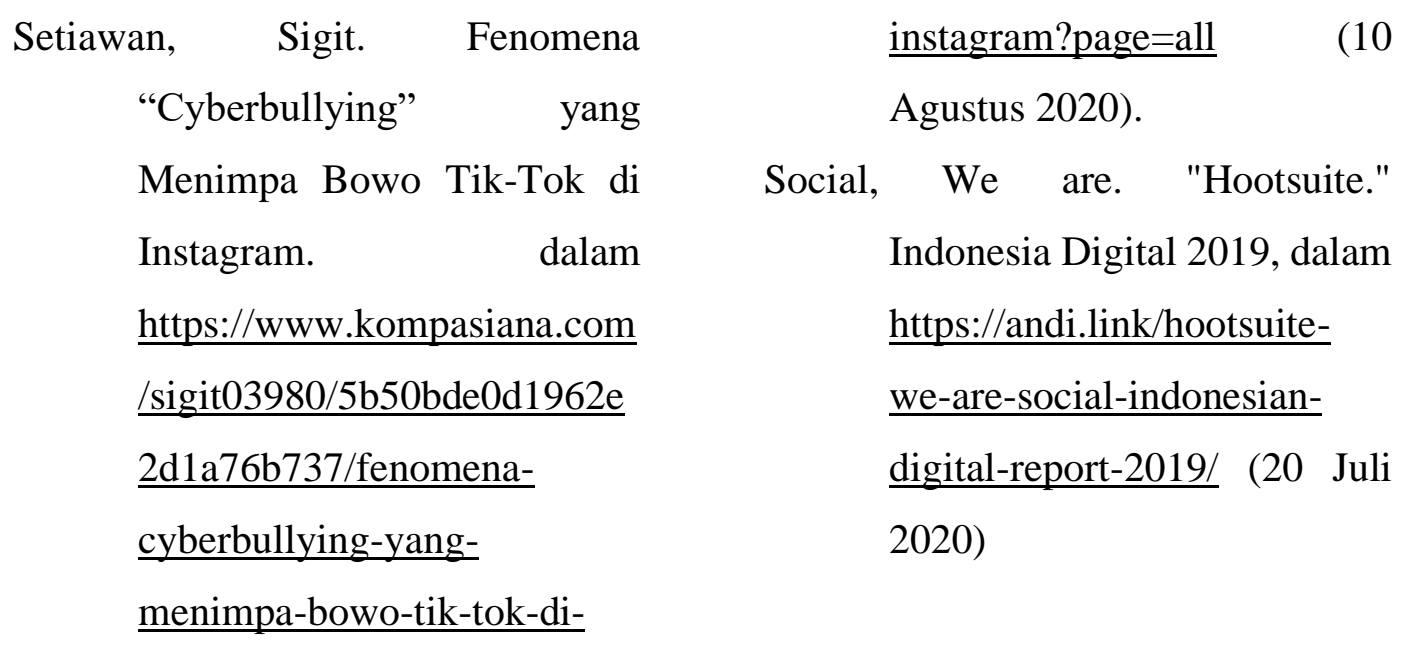

